\title{
TINGKAT HERBIVORI DAUN Avicennia marina (FORSSK.) VIERH DAN Rhizophora mucronata DI VEGETASI MANGROVE - TIMBULSLOKO, DEMAK
}

\author{
Eldita Amalia, Rini Pramesti, Rudhi Pribadi, Wilis Ari Setyati \\ Departemen IImu Kelautan, Fakultas Perikanan dan IImu Kelautan, \\ Universitas Diponegoro,Semarang,Indonesia \\ E-mail: rinipramesti63@gmail.com
}

Received June 2019, Accepted August 2019

\begin{abstract}
ABSTRAK
Mangrove merupakan varietas komunitas pantai tropik dan subtropik yang mampu beradaptasi dengan salinitas tertentu. Jenis Avicennia marina dan Rhizophora mucronata merupakan tegakan alami dan hasil rehabilitasi. Kegiatan konservasi di lokasi ini belum dikelola baik sehingga struktur dan komposisi bervariasi. Hal ini dapat diatasi yang salah satunya dengan herbivori sebagai parameter tingkat kerusakan ekosistem mangrove. Daun merupakan salah satu bagian tumbuhan yang mengalami perubahan bentuk karena pemangsaan. Tujuan penelitian ini untuk mengetahui tingkat herbivori daun A.marina dan $R$. mucronata berdasarkan perbedaan spesies, umur daun dan ketinggian pohon. Metode deskriptif digunakan dalam penelitin ini dan penentuan lokasi pengambilan sampel dengan metode purposive sampling. Sampel daun diambil dari tiga kategori ketinggian yang berbeda yaitu <1 $\mathrm{m},>1-3 \mathrm{~m},>3-5 \mathrm{~m}$, masing-masing sebanyak 10 ulangan (pohon) untuk setiap kategori. Daun dipisahkan berdasarkan umur daun (tua atau muda) dan kondisi daun (utuh atau rusak) dan total daun diambil sebanyak $10 \%$. Hasil penelitian menunjukan nilai rerata pada setiap jenis, umur daun dan ketinggian pohon diperoleh tingkat herbivori $A$. marina yaitu $4,66 \%(0,16 \%-8,93 \%)$ sampai $11,59 \%$ $(2,14 \%-21,97 \%)$ sedangkan $R$. mucronata yaitu $5,23 \%(0,31 \%-9,94 \%)$ sampai $12,44 \%(3,50 \%-23,81 \%)$.
\end{abstract}

Kata Kunci : A. marina, R. mucronata, Herbivori, Timbulsloko

\begin{abstract}
HERBIVORY LEVEL OF MANGROVE LEAVES Avicennia marina (FORSSK.) VIERH AND Rhizophora mucronata IN MANGROVE VEGETATION - TIMBULSLOKO, DEMAK. Mangroves are variety of tropical and subtropical coastal communities that adapt to certain salinity. Avicennia marina and Rhizophora mucronata were found in location. Conservation activities were not managed so the structure and composition varies. This can be overcome one of them with herbivory as a parameter of
\end{abstract}


the level damage to mangrove ecosystems. The leaves are one part of the plant that changes shape due to predation. The purpose of this study was to determine herbivory level of A.marina and $R$. mucronata leaves based on differences in species, leaf of age and tree of height. Descriptive method is used in this study and the determination of the location sampling with the purposive sampling method. Leaf samples were taken from three different height categories namely $<1 \mathrm{~m},>1-3 \mathrm{~m},>3-5 \mathrm{~m}$, each with 10 replications (trees) for each category. The leaves are separated based on the age of the leaves (old or young) and the condition of the leaves (whole or damaged) total leaves taken as much as $10 \%$. The results showed the average value of each species, leaf age and height of the tree obtained $A$. marina herbivory level of $4.66 \%$ range $(0.16 \%-8.93 \%)$ to $11.59 \%$ range $(2.14 \%$ $21.97 \%)$ while $R$. mucronata is $5.23 \%$ range $(0.31 \%-9.94 \%)$ to $12.44 \%$ range $(3.50 \%-23.81 \%)$.

Keywords : A. marina, R. mucronata, Herbivory, Timbulsloko

\section{PENDAHULUAN}

Ekosistem mangrove merupakan ekosistem yang berfungsi sebagai habitat, tempat pertumbuhan ikan-ikan dalam fase juvenile dan atau dalam satu fase hidup dari beberapa jenis ikan, dan tempat berlindung serta juga sumber makanan bagi sebagian besar ikan (Nanjo et al., 2014). Ekosistem mangrove ini dipengaruhi aktivitas pasang surut, keberadaan tumbuhan dan asosiasi jenis biota (Dien et al., 2016; Pangandaheng et al., 2018). Hutan mangrove sebagai tumbuhan litoral yang terlindung dari ombak yang besar dan umumnya tersebar di daerah tropis dan subtropis (Saenger, 2002). Hutan ini berfungsi dalam perputaran nutrien, tempat memijah berbagai biota, menjaga garis pantai, pariwisata, makanan olahan, obat-obatan dan lain-lain (Kordi, 2012).

Jenis mangrove yang terdapat di Timbulsloko adalah Avicennia marina dan Rhizopora mucronata yang merupakan tegakan alami dan hasil rehabilitasi. Luasan mangrove di kedua lokasi ini berkurang karena konversi lahan, abrasi, dan beberapa faktor lain yang salah satunya aktivitas herbivori (Saputro et al. 2009). Soenardjo (2013) herbivori merupakan memakan sebagian atau keseluruhan jaringan tumbuhan oleh konsumen. Faktor yang mempengaruhi herbivor yang berasal dari luar seperti umur daun, ketinggian, cahaya, waktu, kelimpahan pohon, spesies pohon inang. Herbivori dapat disebabkan adanya herbivora yaitu binatang yang memakan jaringan tumbuhan diantaranya detrivor, jamur, virus, serangga pemangsa daun (phytopagus), pemakan akar, parasit tumbuhan, pemakan benih (granivorous), hewan pemakan bunga dan buah. Herbivori juga menguntungkan sebagai kontrol ekologi sedangkan yang merugikan terjadinya penurunan fotosintat (hasil fotosintesis). Septyaningsih ( 2014) menambahkan kandungan zat kimia dan palatabilitas juga mempengaruhi tingkat herbivori daun. Penelitian tentang herbivori daun mangrove yang sudah dilakukan (Elfriyeldi et al., 2018) dan Septyaningsih (2015) di Segara Anakan (2014). Mengingat peranan 
penting vegetasi mangrove, maka penelitian ini dilakukan untuk mengetahui tingkat herbivori pada spesies, ketinggian dan umur daun mangrove di Dusun Bogorame, Timbulsloko.

\section{MATERI DAN METODE}

Materi penelitian berupa jenis daun $A$. marina dan $R$. mucronata yang diperoleh dari Desa Timbulsloko - Demak. Metode penelitian yang digunakan yaitu metode deskriptif yang bertujuan untuk membuat gambaran mengenai kejadian yang diteliti dan dikaji (Hamdi \& Bahruddin, 2014) dan pengambilan sampel secara purposif. Penentuan lokasi penelitian dengan metode purposive atau berdasarkan pertimbangan peneliti yaitu vegetasi mangrove yang diduga mengalami herbivori pada daun (Etikan et al., 2018).

Pengambilan sampel daun dilakukan pada 2 jenis mangrove dengan kategori ketinggian yang berbeda ( $<1 \mathrm{~m},>1-3 \mathrm{~m}$ dan $>3-5 \mathrm{~m})$. Masing-masing kategori dengan 10 pohon. Daun yang sudah diambil, dipisahkan berdasarkan umur (muda atau tua), kondisi daun (utuh atau rusak) dan diambil sebanyak 10\% pada setiap pohon (Pribadi, (1998). Proses selanjutnya diolah menggunakan Software Image $j$ untuk mengukur luas area daun $(\mathrm{cm})$ dan Software Measure picture untuk mengukur panjang dan lebar daun utuh atau rusak $(\mathrm{cm})$. Hasil dari kedua program ini menghasilkan nilai luas area daun dan persen herbivori.

\section{Analisa Data}

Analisa data dilakukan untuk mengetahui nilai luas area daun terhadap panjang dan lebar daun rusak dengan persamaan regresi menggunakan rumus pada software SPSS 24 yaitu:

$(Y=a+b X)$

Keterangan :

a : titik potong kurva terhadap sumbu y

b : kemiringan (slope) kurva linier

$\mathrm{x} \quad$ : variable independent

Persentase herbivori yang diperoleh selanjutnya diklasifikasikan berdasarkan persentase luasan daun hilang (imaginer) dengan rumus :

$\left(\frac{\text { PLA-ALA }}{\text { PLA }}\right) \times 100 \%=\%$ tingkat herbivori

Keterangan :

ALA : (Actual Leaf Area).

PLA : (Potensial Leaf Area). 


\section{HASIL DAN PEMBAHASAN}

Sampel yang diperoleh dari keseluruhan daun (muda atau tua) dan (utuh atau rusak) dari 3 kategori ketinggian $(<1 \mathrm{~m},>1-3 \mathrm{~m}$ dan $>3-5 \mathrm{~m}$ ). Jumlah daun $A$. marina sebanyak 3.152 daun dan $R$. mucronata sebanyak 1.641 daun.

Hasil penelitian tentang rerata tingkat persentasi kerusakan daun (muda dan tua) A.marina (Tabel 1 dan 2).

Tabel 1. Rerata Tingkat Persentase Kerusakan Daun Muda A. marina

\begin{tabular}{llll}
\hline \multirow{2}{*}{ Jenis } & \multirow{2}{*}{ Ketinggian $(\mathrm{m})$} & \multicolumn{3}{l}{ Muda } \\
\cline { 3 - 4 } A. marina & $<1$ & Rerata $(\%)$ & Kisaran $(\%)$ \\
& $>1-3$ & $4,66 \pm 2,58$ & $(0,16-8,93)$ \\
& $>3-5$ & $8,35 \pm 3,13$ & $(1,56-17,80)$ \\
& & $10,74 \pm 3,91$ & $(2,24-22,59)$ \\
\hline
\end{tabular}

Tabel 2. Rerata Tingkat Persentase Kerusakan Daun Tua A. marina

\begin{tabular}{clll}
\hline \multirow{2}{*}{ Jenis } & \multirow{2}{*}{ Ketinggian $(\mathrm{m})$} & Tua & \\
\cline { 3 - 4 } A. marina & $<1$ & Rerata $(\%)$ & Kisaran $(\%)$ \\
& $>1-3$ & $5,07 \pm 2,58$ & $(1,27-9,30)$ \\
& $>3-5$ & $9,15 \pm 3,25$ & $(2,03-18,29)$ \\
& & $11,59 \pm 4,49$ & $(2,14-21,97)$ \\
\hline
\end{tabular}

Hasil penelitian tentang rerata tingkat persentasi kerusakan daun (muda dan tua) dan distribusi persentase herbivori kelas kerusakan berdasarkan total keseluruhan daun R. mucronata (Tabel 3 dan 4).

Tabel 3. Rerata Tingkat Persentase Kerusakan Daun Muda R. mucronata

\begin{tabular}{llll}
\hline Jenis & Ketinggian $(\mathrm{m})$ & Muda & \\
\cline { 3 - 4 } & & Rerata $(\%)$ & Kisaran $(\%)$ \\
\hline R. mucronata & $<1$ & $5,23 \pm 2,99$ & $(0,31-9,94)$ \\
& $>1-3$ & $10,09 \pm 3,87$ & $(1,85-19,75)$ \\
& $>3-5$ & $11,91 \pm 4,88$ & $(2,28-24,82)$ \\
\hline
\end{tabular}

Tabel 4. Rerata Tingkat Persentase Kerusakan Daun Tua R. mucronata

\begin{tabular}{lccl}
\hline Spesies & Ketinggian $(\mathrm{m})$ & \multicolumn{2}{c}{ Tua } \\
\cline { 3 - 4 } & & Rerata $(\%)$ & Kisaran $(\%)$ \\
\hline R. mucronata & $<1$ & $5,94 \pm 2,02$ & $(1,63-8,70)$ \\
& $>1-3$ & $11,37 \pm 2,60$ & $(2,56-17,91)$ \\
& $>3-5$ & $12,44 \pm 4,93$ & $(3,50-23,81)$ \\
\hline
\end{tabular}


Mangrove merupakan tumbuhan seperti pada umumnya mengalami herbivori. Herbivori memiliki keuntungan sebagai kontrol ekologi sedangkan kerugiannya terjadi kerusakan struktur dan komposisi vegetasi. Jumlah daun $A$. marina dan $R$. mucronata yang diperoleh sebanyak 4.793. Kondisi daun utuh dan rusak pada ketinggian $<1 \mathrm{~m},>1-3 \mathrm{~m},>3-5 \mathrm{~m}$ di masing-masing kategori ketinggian pada 10 pohon. Nilai persen tingkat herbivori yang diperoleh berbeda tergantung dari jenis pohon. Hasil tertinggi diperoleh $A$. marina dan $R$. mucronata pada daun tua. Semakin tinggi pohon nilai persentase kerusakan daun semakin meningkat.

Hasil penelitian tingkat persen herbivori ketinggian pada setiap pohon berbeda, semakin tinggi pohon maka nilai persennya semakin besar. Kategori kerusakan tertinggi $>3-5 \mathrm{~m}$ dan terendah di ketinggian $<1 \mathrm{~m}$. Rerata tingkat herbivori tertinggi pada A.marina daun tua pada ketinggian $>3-5 \mathrm{~m}=11,5 \%$ dan terendah pada ketinggian $<1 \mathrm{~m}$ pada daun muda $=4,66 \%$. $R$. mucronata tingkat herbivori tertinggi pada daun tua ketinggian $>3-5 \mathrm{~m}=12,44 \%$ rerata terendah pada ketinggian $<1 \mathrm{~m}$ yaitu $=$ $5,23 \%$.

Hasil penelitian rerata tingkat herbivori tertinggi pada kedua jenis yaitu ketinggian pohon $>3-5 \mathrm{~m}$ pada $A$. marina muda sebesar $10,74 \%$ (kisaran 2,24\% - 22,59\%), tua 11,59\% (kisaran 2,14\% - 21,97\%). $R$. mucronata muda 11,91\% (kisaran 2,28\% - 24,82\%), tua 12,44\% (kisaran $3,50 \%-23,81 \%$ ). Hal ini diduga pohon dengan ketinggian $>3-5 \mathrm{~m}$ menerima cahaya matahari yang dibutuhkan untuk proses fotosintesis lebih banyak dibandingkan pohon dengan ketinggian $<1 \mathrm{~m}$. Hasil penelitian berbeda pada lokasi yang sama (Soenardjo, 2013) menunjukkan tingkat pemangsaan Rhizophora pada ketinggian $>2-3 m$ lebih tinggi dibandingkan ketinggian $>1-2 m$. Jenis $A$. marina lebih tinggi tingkat kerusakan pada ketinggian $>1-2 m$ dibandingkan ketinggian $>2-3 m$. Hal ini disebabkan pengaruh penggenangan dari proses pasang surut. Daun yang terendam menyebabkan spesies di perairan dapat mengkonsumsi daun pada ketinggian $>1-2 m$.

Hasil rerata jenis $A$. marina persen tingkat herbivori terendah $4,66 \%$ (kisaran 0,16\% - 8,93\%) dan tertinggi 11,59\% (kisaran 2,14\% - 21,97\%) (Tabel 1) sedangkan R. mucronata terendah 5,23\% (kisaran $0,31 \%$ $19,75 \%$ ) dan tertinggi $12,44 \%$ (kisaran 3,50\% - 23,81\% (Tabel 3). Hal ini diduga kepadatan vegetasi berbeda menghasilkan nilai persen yang berbeda juga. Kepadatan vegetasi $R$. mucronata ditemukan mengelompok sedangkan $A$. marina lebih menyebar, sehingga persen herbivori $R$. mucronata lebih tinggi. Semakin tinggi kepadatan maka serangga dapat memilih lebih banyak pohon lain. Hasil penelitian ini sesuai Johnstone (1981) tumbuhan dengan pohon lebih rapat memungkinkan herbivora mudah berpindah dibandingkan dengan kondisi pohon yang renggang. $\mathrm{Hal}$ ini akan berpengaruh pada kerusakan daun. Jenis kepiting tersebut yaitu Aratus pisonii, Sesarma rectum, Goniopsis cruentata, Chasmagnathus granulata, serangga dan semut (Brogim \& Lana 1997, Faraco \& Lana 2004). Ditambahkan Farnsworth \& Ellison (1993) faktor yang mempengaruhi herbivori yaitu musim karena dapat menyebabkan persen tingkat herbivora yang berbeda. Avicennia termasuk tumbuhan 
yang tumbuh disetiap musim, sehingga diduga daun yang diambil pada penelitian ini merupakan daun baru yang belum terkena herbivori dibandingkan dengan Rhizophora.

Hasil penelitian rerata umur daun di kedua spesies menunjukan kerusakan tertinggi pada ketinggian $>3-5 \mathrm{~m}$. Daun tua dengan rerata $A$. marina $11,59 \%$ dan $R$. mucronata $12,44 \%$ lebih besar dibandingkan rerata daun muda $A$. marina $10,74 \%$ dan $R$. mucronata $11,91 \%$. Hal ini diduga dapat meningkatkan herbivori pada daun tua karena daun muda lebih disukai karena herbivora menyerang daun sejak kondisi kuncup atau muda. Ketika daun mengalami fase tua luasan yang rusak semakin besar karena ukurannya bertambah. Ditambahkan (Aide, 1993) daun muda menjadi lebih menarik bagi herbivor karena memiliki kandungan nutrisi yang lebih baik dibanding daun tua. Hal lain yaitu daun muda mempunyai kandungan serat yang rendah dibandingkan dengan daun tua, sehingga daun muda lebih disukai untuk dikonsumsi. Selain itu akumulasi pemangsaan daun yang sudah dimulai pada saat daun masih muda. Tingkat pemangsaan daun A.marina yang tinggi terjadi pada daun yang muda. Kandungan tannin yang ada di daun berfungsi melindungi jaringan daun dari pemangsaan atau berfungsi sebagai zat anti herbivori. Selain itu fungsi dari tannin adalah mencegah pembusukan pada jaringan tumbuhan. Daun muda diduga lebih enak dan disukai herbivor karena kandungan nitrogennya lebih tinggi, banyak mengandung air, lunak, dan mudah dicerna. Franswoht \& Ellison (1993) secara umum kualitas nutrisi menunjukkan penurunan di usia yang lebih tua, sehingga daun tua kurang disukai herbivor. Palatabilitas (kelezatan) daun diduga juga berpengaruh pada tingkat herbivori. Daun muda terletak lebih terbuka dibanding daun tua sehingga lebih banyak terkena sinar matahari sehingga daun yang memperoleh cahaya matahari akan menghasilkan produk fotosintesis yang lebih tinggi dibanding daun yang ternaungi (Basset (1991 dalam Septyaningsih et al., 2015).

Hasil penelitian tentang kerusakan daun menunjukan termasuk pada Kelas I (<4,00\%), Kelas II (>4,01\%-8,00\%) dan Kelas III (>8,01\%). Kelas tersebut merupakan persentase dari hasil kedua jenis sehingga dimasukan kedalam 3 kategori. Luasan daun yang dimangsa tergolong rendah. Hal ini diduga berpengaruh pada produktivitas primer mangrove dan perairan ekitar. Ditambahkan (Farnsworth \& Ellison, 1993), terjadinya penurunan pada produktivitas primer sebesar 5-20\% di perairan disebabkan adanya herbivori. Sunardjo (2013) menambahkan hilangnya jaringan daun akibat herbivori akan menghambat fungsi daun sebagai tempat fotosintesis. Proses ini dapat berlangsung adanya perubahan energi kimia dan senyawa karbon menjadi bahan organik dengan bantuan sinar matahari.

\section{KESIMPULAN}

Rerata persen tertinggi $A$. marina daun tua ketinggian $>3-5 \mathrm{~m}$ yaitu $11,59 \%$ (kisaran 2,14\%-21,97\%) dan terendah pada daun muda ketinggian $<1 \mathrm{~m} \mathrm{4,66 \%}(0,16 \%-8,93 \%)$ sedangkan Rerata persen tertinggi 
daun tua ketinggian $>3-5 m$ pada $R$. mucronata sebesar $12,44 \%(3,50 \%-$ $23,81 \%$ ) dan rerata terendah pada daun muda ketinggian $<1$ yaitu $5,23 \%$ $(0,31 \%-9,94 \%)$.

\section{DAFTAR PUSTAKA}

Aide, T. M. 1993. Pattern of Leaf Development and Herbivory in a Tropical Understory Community. Ecological Society of America. Ecology 74 (2): 455-566.

Brogim, R. A. \& Lana, P. C. 1997. Espectro alimentar de Aratus pisonii, Chasmagnathus granulata e Sesarma rectum (Decapoda, Grapsidae) em um manguezal da Baía de Paranaguá, Paraná. Iheringia Série Zoológica, 83: 35-43

Dien A. M. Rembet, U. N. Wantasen, A. S. (2016). Profile of Mangrove Ecosystem in Bahoi Village North Minahasa Regency. Platax 4(1), 1-8.

Etikan, Musa, Alkasim. 2018. Comparison of Convenience Sampling and Purposive Sampling American. Journal of Theoretical and Applied Statistics 2016; 5(1): 1-4. Asian Journal of Environment, History and Heritage. Vol. 2, Issue. 1, p. 113-121. ISSN 2590-4213 e-ISSN 2590-4310

Elfriyeldi., Ahmadryadi., B. Amin. 2018. Kondisi Morfometrik Rhizophora apiculata pada Kawasan dengan Aktivitas Antropogenik Berbeda di Pesisir Timur Indragiri Hilir, Sumatra. Asian Journal of Environment, History and Heritage. Vol 2(1), 113-121

Farnsworth, E.J; A. M. Ellison. 1993. Pattern of Herbivory in Belizean Mangrove Swamps. Biotropica 23(4b): 555-567.

Faraco, L. F. D. \& Lana, P. C. 2004. Leafconsumption levels in subtropical mangroves of Paranaguá Bay (SE Brazil). Wetlands Ecology and Managament, 12: 115-122.

Hamdi, A.S., E. Baharuddin. 2014. Metode Penelitian Kuantitatif Aplikasi dalam Pendidikan. Yogyakarta: Deepublish

Johnstone, I.M. 1981. Consumption of Leaves by Herbivories in Mixed Mangrove Stand. Biotropica, 13 (4); 252-29

Kordi K., Ghufron M. 2012. Ekosistem Mangrove: Potensi, Fungsi, dan Pengelolaan. Perpustakaan Nasional RI: Katalog dalam Terbitan KTD. hlm 273. 
Nanjo, K., Kohno, H., Nakamura, Y., Horinouchi, M., Sano, M. 2014. Effects of Mangrove Structure on Fish Distribution Patterns and Predation Risks. Journal of Experimental Marine Biology and Ecology, 461, 216-225.

Pangandaheng, R. A., Bataragoa, N. E., Tombokan, J. L. 2018. Fish Species and Abundance in the Intertidal Zone around Unsrat Marine Station, East Likupang District, North Minahasa Regency. Platax 6(1), 107-116.

Pribadi, R. 1998. The Ecology of Mangrove Vegetation in Bintuny Bay, Irian Jaya Indonesia. Departement of Biological Molecular Sciences. University of Stirling, Scotland. (Ph.D. Thesis Unpublished)

Saenger P. 2002. Mangrove Ecology, Silviculture and Conservation.London: Kluwer Academic Publisher.

Saputro, G.B., S. Hartini, S.Sukardjo, Al Susanto, A.Poniman. 2009. Peta Mangroves Indonesia. Bakorsurtanal. Jakarta.

Septyaningsih. E, Ardli E.R, Widyastuti A. 2015. Studi Morfometri dan Tingkat Herbivori Daun Mangrove Di Segara Anakan Cilacap. Scripta Biologica 1 (2) 137-140.

Soenardjo, N. 2013. Pemangsaan Daun Rhizophora stylosa Griff dan Avicennia marina (Forsk) Vierh. Buletin Oseanografi Marina. Vol.2. 41-47. 